\title{
Impact of Covid-19 on Livestock Production Chain and its Consequences on Food Security: A Review
}

\author{
Jean Bosco Nzeyimana ${ }^{1,2}$, Joseph Butore ${ }^{2}$, Libère Ndayishimiye ${ }^{2,3}$, Melchior Butoyi ${ }^{4}$
}

10.18805/ag.DF-395

\begin{abstract}
Covid-19 represents an unprecedented public health threat and a severe crisis of society globally. Government agencies, policymakers and the global institutions, on the other hand, should give particular attention to and try to alleviate the problem (present and prospective) of the pandemic and related crisis response on key sectors that contribute to food stability, nutrition and livelihoods. The livestock sector plays an essential role in these areas, particularly for the particularly vulnerable population groups. Covid-19's effects on livestock production are still largely unsubstantiated and not fully felt. Although case studies are not yet possible, observational data show interruptions in livestock's entire value chain. The consequences of Covid-19 on the livestock production chain are in particular interruptions throughout the entire livestock value chain, lack of sales markets, import/export restrictions due to border closures, substantial financial losses to producers, increased cases of food insecurity.
\end{abstract}

Key words: Covid-19, Global food security, Global health crisis, Livestock production chain.

Several cases of atypical pneumonia caused by the severe acute respiratory syndrome coronavirus-2 (SARS-CoV-2) were reported in Wuhan, China, in December 2019 (Lu et al., 2020; Zangrillo et al., 2020). This novel virus has now caused a pandemic [coronavirus disease 2019 (COVID-19)] (Zangrillo et al., 2020). The COVID-19 pandemic has had a tremendous effect on people worldwide; in just over a year, more than 106 million cases of infections have been confirmed globally and more than 2.3 million people have died(Lin and Vazquez, 2021). The recent outbreak of COVID19 , a coronavirus-associated acute respiratory disease, is the third recorded overspill of an animal coronavirus to humans in the only couple of decades, leading to a significant epidemic (Gorbalenya et al., 2020). The International Committee on Taxonomy of Viruses' Coronaviridae Study Group (CSG), responsible for developing virus categorization and taxon classification for the family Coronaviridae, has evaluated the placing of the human pathogen, provisionally named 2019-nCoV, within the Coronaviridae (Gorbalenya et al., 2020).

The emerging coronaviral infection named as COVID19 was officially declared as pandemic on 11, March 2020 by the World Health Organization (WHO)(Cucinotta and Vanelli, 2020; Vijayaraghavan et al., 2020). Restrictions in Argentina, the world's largest soymeal exporter, have cut soy supply to feed mills in half, potentially disrupting global trade flows; and travel restrictions disrupt transhumance, limiting pastoralists' ability to feed livestock (FAO, 2020a). The COVID-19 pandemic and subsequent lockdown have created unprecedented emergency and sudden distress on all sectors including the livestock sector (Saravanan et al., 2021). COVID-19 has put unprecedented stressors on food supply chains, causing inefficiencies in farm labor, manufacturing, transportation and logistical support, along
${ }^{1}$ College of Animal Science and Technology, Anhui Agricultural University, 130 Changjiang West Road, 230036 Hefei, P.R of China. ${ }^{2}$ Faculty of Agronomy and Bio-Engineering, University of Burundi, 2 Avenue de l'UNESCO, 1550 Bujumbura, Burundi.

${ }^{3}$ College of Food Science and Technology, Huazhong Agricultural University, 1 Shizishan street, 430070 Wuhan, P. R of China.

${ }^{4}$ Ministry of Environment, Agriculture and Livestock, 13 Avenue Mwambutsa, 1850 Bujumbura, Burundi.

Corresponding Author: Jean Bosco Nzeyimana, College of Animal Science and Technology, Anhui Agricultural University, 130 Changjiang West Road, 230036 Hefei, P.R. of China.

Email: nzeyimana26@gmail.com

How to cite this article: Nzeyimana, J.B., Butore, J., Ndayishimiye, L. and Butoyi, M. (2021). Impact of Covid-19 on Livestock Production Chain and its Consequences on Food Security: A Review. Agricultural Science Digest. DOI: 10.18805/ag.DF-395.

Submitted: 14-08-2021 Accepted: 22-10-2021 Online: 09-11-2021

with significant demand shifts. In the face of these challenges, food supply chains have shown remarkable resilience (OECD, 2020a, 2020b). COVID-19 has impacted food trade, food supply chains, markets, livelihoods and nutrition. As one of the main pillars of food security, the livestock production industry has not even been spared by the covid-19 pandemic consequences. Among the many effects, we can cite the drop in the production of feed for livestock, the decrease in animal production (meat, milk, eggs, etc.), the losses of breeders, the failures of feed manufacturers and shortages, the flow market (MarchantForde and Boyle, 2020). This review aimed to overview the impact of covid-19 on the livestock production chain and its consequences on food security. 
Impact of Covid-19 on Livestock Production Chain and its Consequences on Food Security: A Review

\section{Impact of covid-19 on the livestock production chain}

Impact of covid-19 on the processing and export of livestock products

The first consequence of animal product processing was to reduce processing capacity; due to lockdown measures, decrease of staff by some companies; as a result, industry capacity for meat and dairy processing declined since teleworking is almost impossible (Biswal et al., 2020).

Table 1 shows some impacts of covid-19 on the livestock sector. Transport was being hampered by movement restrictions, decreasing livestock and livestock products (FAO, 2020b). Until movement bans were lifted in the Philippines, delays in vehicles transporting raw materials for processing meat threatened to cause a shortage (Gomez, 2020). Tight road traffic controls in China interrupted milk processing and transportation, resulting in milk dumping (FAO, 2020a). The total stoppage of international transport has had a major impact on the export of livestock products. It has been noticed within the European Union where $35 \%$ of beef is exported between member countries. A recent ban on exports caused farm gate prices to fall in Poland, as domestic consumption only represents $15 \%$ production (FAO, 2020c). In Australia, the panic buying of meat products by consumers and the COVID-19 infections in processing plant workers slowed processing capacity; in addition, there was a decreased demand for meat products from restaurants and the simultaneous closure of international borders that reduced the export of products (D'Souza and Dunshea, 2021; Gauly et al., 2021). Movement restrictions have also stopped livestock trade to China from the Lao People's Democratic Republic, Myanmar, Thailand and Viet Nam. Because they couldn't export their products, livestock producers, traders and butchers lost money. Drops in meat exports in Latin America, particularly in Argentina and Uruguay, have reduced farmer income.(FAO, 2020c).

\section{Some measures taken by certain countries affecting the animal production sector in the context of the covid-19 pandemic}

Most countries have imposed significant reductions in the transport of goods (land, ocean freight and air freight), transportation-dependent services and domestic and international labor migration to fight against the COVID19 pandemic. Workers are in short supply as a result of transportation system disruptions as well as diseaseprevention restrictions(FAO, 2020b; Schmidhuber et al., 2020). These conditions led to global disruptions in food supply chain logistics, impede food transportation and farm income and endanger food safety and nutrition, especially in developing countries(FAO, 2020d). Smallholder pastoral households have struggled to find alternative sources of income, limiting their ability to make money(FAO, 2020a). The COVID-19 outbreak coincided with rainfall when farmers were restricting livestock sales to increase milk, livestock and cattle output. Instead, they pursue alternative sources of income such as milk trading, farm work, or local commodity markets. The market closures and restrictions on movement associated with COVID-19 have reduced domestic income from these alternative sources (Lynch and Corps, 2020). For example, in China, soybean processing has been hampered by a slowdown in Brazilian exports caused by a lack of freight capacity from Mato Grosso to the country's ports. China has also banned importing meat from some slaughterhouses in several countries (Gu et al., 2020). Table 2 shows a summary of some impacts of covid-19 on import /export in livestock product sector in China. This measure has resulted in a soybean shortage for Chinese crushers, a situation that, according to China Oil and Foodstuffs Corporation (COFCO), could last longer.

Similarly, the virtual halt in passenger flights used to transport fruits and vegetables in the cargo body has decreased the availability of certain fruits and vegetables, mainly tropical fruits. For example, India reported a significant decrease in fruit and vegetable export (Schmidhuber et al., 2020). The Philippine Association of Meat Processors Inc (PAMPI) warned at the end of August 2020 that the government banned on poultry products, including mechanically deboned meat (MDM) from Brazil, would result in a shortage of raw materials and raise prices for canned food products in the country (FAO, 2020b).

Impact of covid-19 on meat and poultry processing plant workers

The animal slaughtering and processing industry in the United States employed an estimated 525,000 workers in approximately 3,500 facilities nationwide; combined data on workers with COVID-19 and COVID-19 related deaths identified and reported through May $31^{\text {st }}$ from 23 states $(16,233$ cases; 86 deaths), at least 17,358 cases and 91 COVID-19 associated mortality have occurred among U.S. meat and poultry processing workers (Gibbins et al., 2020). In recent months, processing plant closures have significantly reduced livestock slaughter volume for both cattle and hogs. The number of federally inspected cattle slaughtered in the week ending April $25^{\text {th }}$ was 469 thousand head, a $27 \%$ decrease from both the first week of 2020 and the same week a year ago (Gibbins et al., 2020).

\section{Impact of covid-19 on the pig industry}

Through pork exports to several Asian countries, including China, South Korea and Illinois, Covid-19 has hurt the pork industry (IPPA, 2020a). Its effects began to influence the Illinois hog industry in early January 2020. The first effects were purely a price impact on live hogs and wholesale pork prices as COVID-19 impacted US pork exports to several Asian markets, including China and South Korea (IPPA, 2020a). Hog slaughter volume has dropped dramatically, with estimates of $15 \%$ less than a year ago and $26 \%$ less than in the first whole week of January(Mintert, 2020). During 


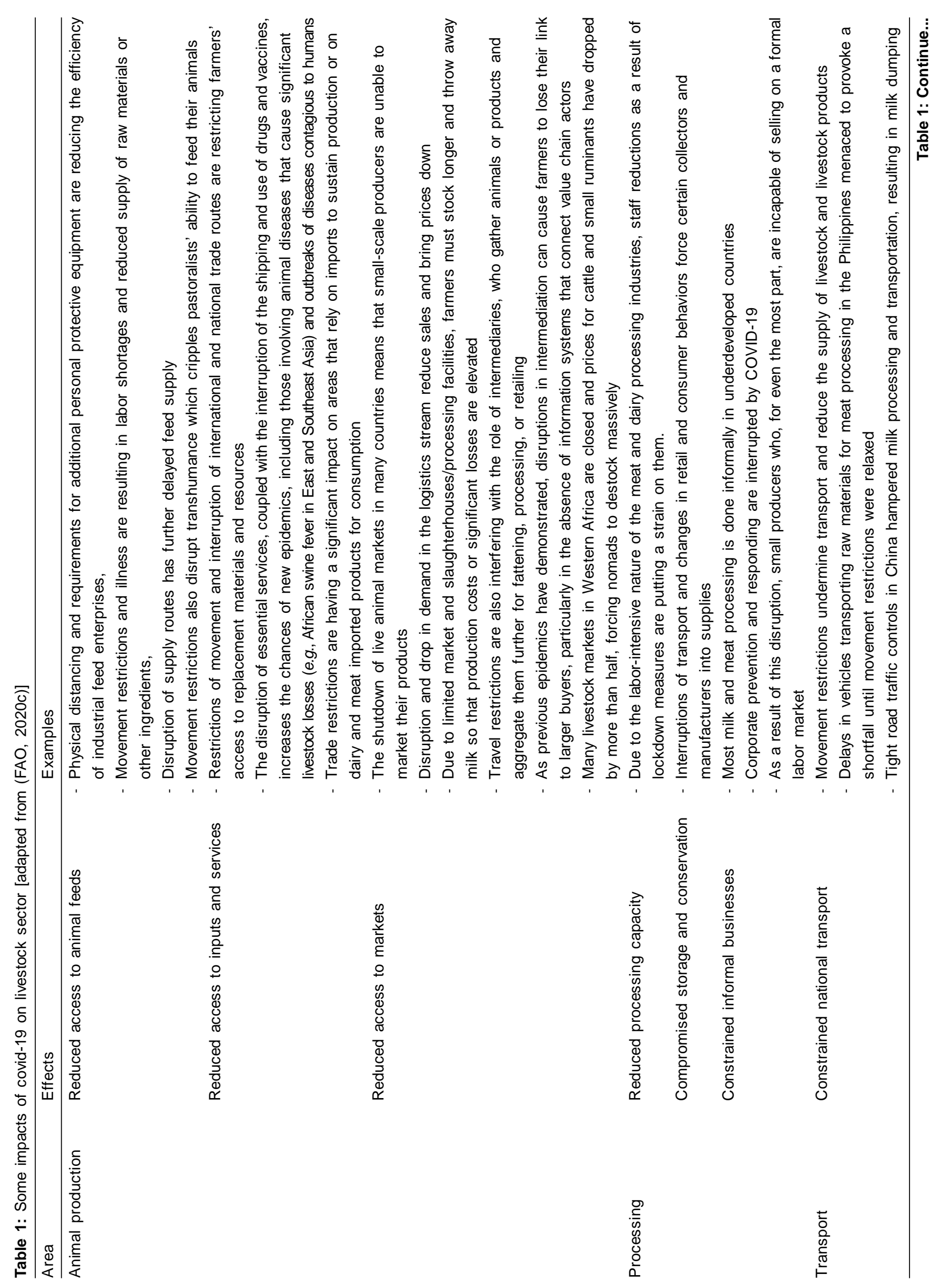




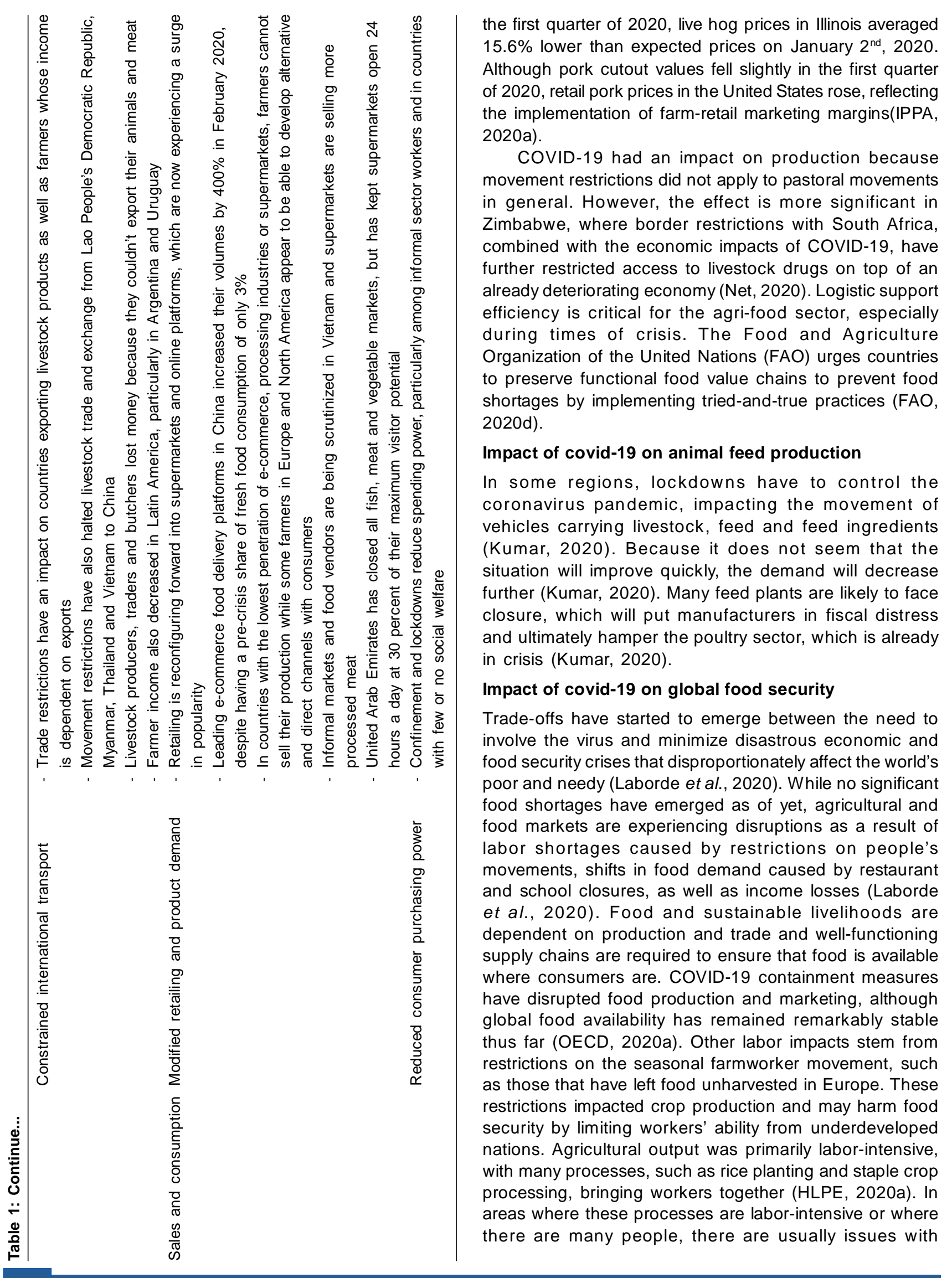


Impact of Covid-19 on Livestock Production Chain and its Consequences on Food Security: A Review

Table 2: Impact of covid-19 on import /export in livestock products: China suspended meat imports from various origins amid the COVID-19 pandemic.

\begin{tabular}{llcl}
\hline Date (in 2020) & Company & Country of origin & Concerned product \\
\hline June 17 & Tönnies group & Germany & Pork products \\
June17 & Brazilian beef processor Agra & Brazil & Beef products \\
June 17 & Britain's largest pork processor Tulip & England & Pork products \\
June 20 & Rosderra Irish Meats Group Ltd & Ireland & Frozen pork and other products \\
June 21 & Tyson Inc & USA & Poultry products \\
June 22 & Frigorífico Rioplatense S.A.I.C.I.F & Argentina & Beef products \\
June 26 & Brazil's JBS Aves Ltd & Brazil & Poultry products \\
June 27 & Brazil's Marfrig & Brazil & Beef products \\
June 28 & Danisch Crown Fleisch GmbH & Germany & Pork products \\
June 28 & Brazil's Companhia Minuano de Alimentos & Brazil & Poultry products \\
June 28 & Cargill Inc & Canada & Beef products \\
June 28 & Dutch companies Van Rooi Meat B.V., VION & Netherlands & Pork products \\
& Groenlo B.V., VION Boxtel B.V. and Westfort V.O.F & & \\
July1 & Argentinian beef producer FRIMSA S.A. & Argentina & Beef products \\
July1 & Ghinzelli S.r.I & Italy & Pork products \\
July 2 & British ABP Food Group (ABP Ellesmere) & England & Beef products \\
July 4 & Westfleisch SCE mbH Meat Center Coesfeld (Westfleisch) & Germany & Pork products \\
July 4 & Westfort Vleesproducten & Netherlands & Pork products \\
July 4 & Brazilian food company BRF SA and a JBS-owned Searabrand & Brazil & Pork products \\
\hline
\end{tabular}

excessive contact and a lack of protection for food and agriculture workers (HLPE, 2020a).

Higher food prices, combined with lower incomes, force an increasing number of households to reduce the quantity and quality of their food consumption, with potentially long-term consequences for nutrition and health. Because of income and remittance losses, the World Food Program has warned that an additional 130 million people may face acute food insecurity by the end of 2020, on top of the 135 million people already acutely food insecure before the crisis (World Bank, 2020). Summarily, World Bank reported that Covid-19 has negatively affected the household's income and food security (World Bank, 2020). There is a risk that resources allocated to combating malnutrition will be reduced, with negative consequences for food security, nutrition and livelihood opportunities (GNAFC, 2020). Specialization in agribusiness, monocropping and the agricultural industry can reduce supply chain resilience (OECD, 2020b). Isolated countrylevel policies, especially in developing countries, were likely to exacerbate food insecurity. Furthermore, the pandemic's potential effect on food production in major food-producing countries (e.g., China, the EU and the United States) could have severe implications for global food security and food prices (HLPE, 2020a). The confinement measures implemented in several countries would have immediate effects and longer-term effects on the worldwide economy (HLPE, 2020a).

The closing of restaurants and retail services and facilities resulted in a significant drop in demand for perishable items such as dairy products, potatoes, fresh fruits and specialty items such as chocolate and some high- value cuts of meat (HLPE, 2020b; Lewis, 2020). Farmers who lacked adequate storage facilities, including cold storage, were left with the food they couldn't sell (HLPE, 2020b).

Such price increases would be felt the most by vulnerable groups who rely on markets for food and those who already rely on humanitarian aid to maintain their living standards and food access. Price increases in food can also cause social tensions and conflict. Higher prices impose or exacerbate economic constraints, which can exacerbate feelings of (perceived) starvation, leading to war (FAO, 2020a).

Since the beginning of the pandemic, governments have prioritized their citizens' health and safety, increasing testing as much as possible and instituting isolation measures to slow down the spread of the disease. It will remain a top priority until a long-term solution can be found (HLPE, 2020a). Meanwhile, authorities have developed every effort to maintain their countries' food security and meet the needs of the most vulnerable people as part of the measures to mitigate the pandemic's economic impact (HLPE, 2020b). The 2014 Ebola virus disease outbreak demonstrated that the implementation of restriction measures caused disruptions 17 in collecting and transporting agricultural products to markets. Reduced demand for perishable products resulted in significant earnings reductions for smallholder family farmers and other small-scale producers (HLPE, 2020a).

\section{CONCLUSION}

COVID-19 is putting pressure on policy makers to make quick decisions to keep food supply chains running. While 
Impact of Covid-19 on Livestock Production Chain and its Consequences on Food Security: A Review

short-term policies can help global food systems adapt, the long-term effects are unknown. There's any need to ensure that brief measures will not become permanent and that policies designed to contribute to long-term goals of resilient, sustainable and productive global food systems are reinforced, not hampered, by policy action and during a crisis. The fundamental task for policymakers is to carry out the necessary measures to address the immediate pandemic disorder while investing in medium and longterm policies to address the triple challenge. Countries should establish strategic food security action plans to manage COVID-19 risks and mitigate their impact on food security and nutrition and the possible destabilizing economic and social impact of this risk. Policy statements should be tailored to the context of each country and should be consistent with the health preparedness and mitigation plan. They should be continuously monitored based on new information and data on global and local food markets and food supply and value chains. The following are recommendations that governments worldwide could consider to deal with the pandemic's short- to mediumterm effects.

\section{Competing interests}

The authors declare that they have no competing interests.

\section{REFERENCES}

Biswal, J., Vijayalakshmy, K. and Rahman, H. (2020). Impact of COVID-19 and associated lockdown on livestock and poultry sectors in India. Veterinary World. 13(9): 19281933. https://doi.org/10.14202/vetworld.2020.19281933.

Cucinotta, D. and Vanelli, M. (2020). WHO declares COVID-19 a Pandemic. In: Acta Biomedica. Mattioli 1885. 91(1): 157160). https://doi.org/10.23750/abm.v91i1.9397.

D'Souza, D.N. and Dunshea, F.R. (2021). Impact of COVID-19 on the Australian pork industry. Animal Frontiers. 11(1): 1922. https://doi.org/10.1093/af/vfaa058.

Gomez, E.J. (2020). Canned meat prices expected to rise. The Manilla Times. https://www.msn.com/en-ph/news/national/ canned-meat-prices-expected-to-rise/ar-BB18x5HAAccessed date 2020.11.16.

FAO. (2020a). Addressing the impacts of COVID-19 in food crises. United Nations. https://doi.org/10.4060/ca9123en.

FAO. (2020b). Coronavirus Disease 2019 (COVID-19)/ Addressing the Impacts of COVID-19 in Food Crises, April-December 2020, May update, FAO's Component of the Global COVID-19 Humanitarian Response Plan (Issue May update). FAO. https://doi.org/10.4060/ca9192en\%0A.

FAO. (2020c). Mitigating the impacts of COVID-19 on the livestock sector. April.

FAO. (2020d). Responding to the impact of the COVID-19 outbreak on food value chains through efficient logistics (Issue April). https://doi.org/doi.org/10.4060/ca8466en.

Gauly, M., Chemineau, P., Rosati, A. and Sartin, J. (2021). COVID-19 pandemic-how and why animal production suffers? Animal Frontiers. 11(1): 3-5. https://doi.org/10.1093/af/vfaa059.
Gibbins, J. D., Hale, C., Silver, M., Fischer, M., Steinberg, J., Basler, C.A., Jacobs, J.R., Kennedy, E.D., Tomasi, S., Trout, D. and Hornsby-myers, J. (2020). COVID-19 among workers in meat and poultry processing facilities. 69(18): 557-561.

GNAFC. (2020). Key takeaways of the Global Network Against Food Crises on Preventing a food catastrophe during the COVID-19 pandemic. Global Network against Food Crises.

Gorbalenya, A.E., Baker, S.C., Baric, R.S., de Groot, R.J., Drosten, C., Gulyaeva, A.A., Haagmans, B.L., et al. (2020). The species Severe acute respiratory syndrome-related coronavirus: classifying 2019-nCoV and naming it SARSCoV-2. Nature Microbiology. 5(4): 536-544. https://doi.org/ 10.1038/s41564-020-0695-z.

Gu, H., Daly, T., Mano, A. and Potter, M. (2020). FACTBOX-China suspends meat imports from various origins amid COVID-19 pandemic. REUTERS. https://www.msn.com/en-us/ news/world/factbox-china-suspends-meat-imports-fromvarious-origins-amid-covid-19-pandemic/ar-BB16hP52; Accessed 2020.11.16

HLPE. (2020a). Impact of COVID-19 on food security and nutrition (FSN). United Nations, March, 1-8.

HLPE. (2020b). Impacts of COVID-19 on food security and nutrition: Developing effective policy responses to address the hunger and malnutrition pandemic. High Level Panel of Experts Issues Paper, September.

IPPA. (2020a). Covid-19 impacts on Illinois hog producers and pork processing industry.

IPPA. (2020b, November 10). Illinois Pork Producers | Covid-19 Impacts. https://ilpork.com/farmers-care/covid-19-impacts.

Kumar, J. (2020). Covid: Indian poultry feed manufacturers incurring losses. All about Feed.

Laborde, B. D., Martin, W., Swinnen, J. and Vos, R. (2020). COVID19 risks to global food security. American Association for the Advancement of Science. 369(6503): 500-502.

Lewis, L. (2020). Coronavirus serves up a surplus of Wagyu beef. Financial Times. https://www.ft.com/content/bb5408392f63-43bc-897c-b73b2d9f6dc7).

Lin, S.K. and Vazquez, F. (2021). COVID: A New Peer-reviewed Journal on Coronaviruses and Coronaviruses-Diseases. Covid. 1(1): 1-1. https://doi.org/10.3390/covid1010001.

Lu, H., Stratton, C.W. and Tang, Y.W. (2020). Outbreak of pneumonia of unknown etiology in Wuhan, China: The mystery and the miracle. Journal of Medical Virology, 92(4): 401-402. https://doi.org/10.1002/jmv.25678.

Lynch, K. and Corps, M. (2020). Covid-19 and Livestock Market Systems the Impact of Covid-19 on Livestock-based economies in the Horn of Africa (Issue August).

Marchant-Forde, J.N. and Boyle, L.A. (2020). COVID-19 Effects on Livestock Production: A One Welfare Issue. Frontiers in Veterinary Science. 7(September): 1-16. https://doi.org/ 10.3389/fvets.2020.585787.

Mintert, J. (2020). Covid-19 Impacts on Pork and Beef. In: Purdue University. Center for Commercial Agriculture. (pp. 1$6)$.

Net, F. (2020). GLOBAL Special Report August 2020 Impacts of COVID-19 on crop and livestock production Global summary East Africa (Issue August, pp. 1-35). FAO. 
Impact of Covid-19 on Livestock Production Chain and its Consequences on Food Security: A Review

OECD. (2020a). COVID-19 and Global Food Systems. OECD, June, 7.

OECD. (2020b). Food Supply Chains and COVID-19: Impacts and Policy Lessons. Comparing Crises: Great Lockdown versus Great Recession, June, 1-11.

Saravanan, K. P., Silambarasan, P., Manivannan, A., Sasikala, V. and Sivakumar, T. (2021). Constraints and management practices of dairy farming during COVID-19 pandemic situation. Asian Journal of Dairy and Food Research. 40(1): 20-24. https://doi.org/10.18805/ajdfr.dr-1620.

Schmidhuber J. and Pound J. and Qiao B. (2020). COVID-19: Channels of Transmission to Food and Agriculture (FAO).
Vijayaraghavan, R., Naveenkumar, V., Nag, B.S.P. and Porteen, K. (2020). The Possible Risk of Reverse Zoonosis in COVID-19: An Epidemiological Driving Approach for the One Health Future Challenges: A Review. Asian Journal of Dairy and Food Research. 39(3): 173-179. https:// doi.org/10.18805/ajdfr.dr-1543.

World Bank. (2020). Food Security and COVID-19. https://doi.org/ BRIEF OCTOBER 15, 2020

Zangrillo, A., Beretta, L., Scandroglio, A.M., Monti, G., Fominskiy, E., Colombo, S., Morselli, F., et al. (2020). Characteristics, treatment, outcomes and cause of death of invasively ventilated patients with COVID-19 ARDS in Milan, Italy. Critical Care and Resuscitation: Journal of the Australasian Academy of Critical Care Medicine. 22(3): 200-211. 